\title{
Heavy metal accumulation in Halimione portulacoides: Intra- and extra-cellular metal binding sites
}

\author{
Ana I. Sousa ${ }^{\mathrm{a}, \mathrm{b}, *}$, Isabel Caçador ${ }^{\mathrm{a}}$, Ana I. Lillebø ${ }^{\mathrm{c}}$, Miguel A. Pardal ${ }^{\mathrm{b}}$ \\ ${ }^{a}$ IO - Institute of Oceanography, Faculty of Sciences, University of Lisbon, Campo Grande, 1749-016 Lisbon, Portugal \\ ${ }^{\mathrm{b}}$ IMAR - Institute of Marine Research, Department of Zoology, University of Coimbra, 3004-517 Coimbra, Portugal \\ c CESAM - Centro de Estudos do Ambiente e do Mar, University of Aveiro, Campus de Santiago, 3810-193 Aveiro, Portugal
}

Received 16 February 2007; received in revised form 2 July 2007; accepted 3 July 2007

Available online 30 August 2007

\begin{abstract}
Salt marsh plants can sequestrate and inherently tolerate high metal concentrations found in salt marsh sediments. This work intended to understand the Halimione portulacoides (L.) Aellen strategies to prevent metal toxicity, by investigating the metal location in different plant organs and in the cell. A sequential extraction was performed on leaves, stems and roots of $H$. portulacoides in order to determine and compare the metal $(\mathrm{Zn}, \mathrm{Pb}, \mathrm{Co}, \mathrm{Cd}, \mathrm{Ni}$ and $\mathrm{Cu}$ ) concentration in several fractions of the plant material (ethanolic, aqueous, proteic, pectic, polissacaridic, lenhinic and cellulosic). This study shows that all plant organs of $H$. portulacoides mostly retain metals in the cell wall ( $65 \%$ is the average for all studied metals stored in the root cell wall, $55 \%$ in the stems and $53 \%$ in the leaves), and the metal content in the intracellular compartment is much lower ( $21 \%$ in roots, $25 \%$ in stems and $32 \%$ in leaves). High levels of heavy metal in the sedimentary environment do not cause toxicity to $H$. portulacoides, because $H$. portulacoides immobilizes them in different cell compartments (cell wall + proteic fraction + intracellular) outside key metabolic sites.
\end{abstract}

(c) 2007 Elsevier Ltd. All rights reserved.

Keywords: Compartmentation; Phytoremediation; Phytotoxicity; Salt marsh; Sequential extraction

\section{Introduction}

Estuarine salt marshes are frequently highly contaminated with metals, due to human and industrial activities occurring in the estuaries and adjacent areas. However, these contaminants must be in an available form for them to be taken up by salt marsh plants (Greger, 2004), which are known to tolerate and accumulate high levels of heavy metals (e.g. Matthews et al., 2005). It seems there is an innate tolerance to metals in wetland plants (McCabe et al., 2001), eventually explained by the biogeochemistry of the rhizosphere (Otte et al., 2004). The solubility and availability of metals for plants may be affected by several

\footnotetext{
* Corresponding author. Address: IO - Institute of Oceanography, Faculty of Sciences, University of Lisbon, Campo Grande, 1749-016 Lisbon, Portugal. Tel.: +351 2175001 48; fax: +351 217500009 .

E-mail address: aisousa@fc.ul.pt (A.I. Sousa).
}

factors such as their loading rate, chemical characteristics, $\mathrm{pH}$, redox potential, soil texture, clay content and organic matter content, cation exchange capacity, etc. (Greger, 2004), which determine the different uptake by different plant species and at different locations. Salt marsh plants have the ability to uptake metals. Metals are then translocated within the plant, at different concentrations in different organs. Salt marsh plants generally accumulate different percentages of metals in the below- and aboveground parts, with a higher percentage of metals in the roots rather than in the above-ground part (Fitzgerald et al., 2003; Matthews et al., 2004). Metal translocation can occur in the phloem, via the apoplast, and via the xylem, acropetally (Greger, 1999). Therefore, metal translocation and storage capacity differs with plant species and with metal (e.g. Stoltz and Greger, 2002).

In order to survive in metal contaminated salt marshes, salt marsh plants may have mechanisms to regulate (and 
distribute) internal and cell wall metal concentrations, according to their tolerance capacity, which determines their survival. Metal tolerance by plants, and heavy metal detoxification may be achieved through metal complexation with ligands such as organic acids, amino acids and some members of the mugineic acids which exist in plant tissues, and also by compartmentation (Hall, 2002; see Carrier et al., 2003 and references therein). So, metals can be stored/accumulated either in cell walls (e.g. Lozano-Rodriguez et al., 1997; Carrier et al., 2003), cytoplasm (Rauser and Ackerley, 1987; Carrier et al., 2003) or in cell vacuoles (e.g. for Cd see Carrier et al., 2003). In order to maximize their detoxification and/or transport, plants control both the oxidation state and coordination environment of specific metallic elements (Salt et al., 2002). Direct coordination of the element (e.g. cadmium, nickel and zinc) by the plant, through the most chemically appropriate ligand leads to stable non-toxic complexes, and this is one of the mechanisms used for detoxification of metals and metalloids (Salt et al., 2002). Moreover, ectomycorhizas can be efficient in diminishing the toxicity effect on the host plant, usually in trees and shrubs (review in Hall, 2002; Liu and Kottke, 2003). Other mechanisms consist of binding metals in soil as highly insoluble metal sulfides, through the precipitation of metals such as zinc, lead and cadmium (Otte et al., 2004). Metals can also be mobilized in the rhizosphere through adsorption and co-precipitation with iron oxy-/hydroxides which circulate as far as the iron plaque (it functions as a metal sink), and are immobilized near the root surface (Otte et al., 2004). Additionally, metals can adsorb to organic matter within the sediments (Fritioff and Greger, 2006) forming metal quelates or complexes (Sauvé et al., 2000; Mellis et al., 2004), also conditionating its bioavailability.

The Tagus estuary is located near a highly populated and industrialized city (Lisbon). According to previous works (Caçador et al., 1996, 2000) the estuary receives discharges from industries (e.g. chemicals and steelmaking) and effluents from anthropogenic sources (including metals) incorporating them in the sediment. Its salt marshes are colonized by several halophyte species, namely Halimione portulacoides (L.) Aellen. These salt marshes retain heavy metals in their sediments, which are largely sequestrated and tolerated by these plants (Caçador et al., 2000; Reboreda and Caçador, 2007). However, the toleration mechanism is not yet completely understood, not even the exact location of metal accumulation in the plants and cells.

Considering the capacity of salt marsh plants to accumulate high concentrations of heavy metal and its useful employment in phytoremediation processes (e.g. Reboreda and Caçador, 2007), the aim of this work is to understand the molecular/cellular mechanisms that control the uptake and detoxification of metals by $H$. portulacoides (a salt marsh plant), and the metal compartmentation and location within the plant cell.

Regarding the previously mentioned effluents and discharges into the Tagus estuary and salt marshes, the most abundant heavy metals at this site were analyzed in this study (zinc, lead, cobalt, cadmium, nickel and copper).

\section{Materials and methods}

\subsection{Sampling site description}

The Tagus estuary, located on the western coast of Europe, has a shallow bay covering an area of about $320 \mathrm{~km}^{2}$. Intertidal mudflats in the Tagus salt marshes are colonized by several halophyte species, with $H$. portulacoides (Caryophyllales: Chenopodiaceae) as one of the most representative, corresponding to $25 \%$ of covered area in the salt marsh plant community. This study was carried out in the Rosário salt marsh (in the Tagus estuary), located near urbanised and industrial areas, thus receiving effluent discharges from these sources, which unequivocally affect these habitats. This salt marsh sediment presented the following heavy metal concentrations among the roots of $H$. portulacoides: $72.9 \pm 14.7 \mu \mathrm{g} \mathrm{g}^{-1}$ DW of $\mathrm{Cu}, 461.8 \pm$ $219.5 \mu \mathrm{g} \mathrm{g}^{-1} \mathrm{DW}$ of $\mathrm{Pb}, 3.6 \pm 0.4 \mu \mathrm{g} \mathrm{g}^{-1}$ DW of Cd (Reboreda and Caçador, 2007), 749.3 $\pm 84.1 \mu \mathrm{g} \mathrm{g}^{-1} \mathrm{DW}$ of $\mathrm{Zn}$, $49.6 \pm 0.04 \mu \mathrm{g} \mathrm{g}^{-1}$ DW of $\mathrm{Ni}, 59.6 \pm 0.05 \mu \mathrm{g} \mathrm{g}^{-1} \mathrm{DW}$ of Co (Caçador, unpublished data). According to Reboreda and Caçador (2007) and Caçador (unpublished data), metals dissolved in porewater at this salt marsh presented the following concentrations: $60.6 \pm 8.5 \mu \mathrm{g} \mathrm{g}^{-1}$ of $\mathrm{Cu}, 247.2 \pm$ $56.7 \mu \mathrm{g} \mathrm{g}^{-1}$ of $\mathrm{Pb}, 95.4 \pm 6.6 \mu \mathrm{g} \mathrm{g}^{-1}$ of $\mathrm{Cd}, 98.5 \pm 15.1$ $\mu \mathrm{g} \mathrm{g}^{-1}$ of $\mathrm{Zn}, 15.3 \pm 2 \mu \mathrm{g} \mathrm{g}^{-1}$ of $\mathrm{Ni}$ and $13.1 \pm 1 \mu \mathrm{g} \mathrm{g}^{-1}$ of Co.

\subsection{Sampling strategy and laboratorial processing}

Samples of $H$. portulacoides plants were collected from monotypic stands in the Rosário salt marsh, in the Tagus estuary. Three squares of $0.3 \times 0.3 \mathrm{~m}^{2}$ were sampled, wherein the above-ground material was collected by harvesting it, and the below-ground material was collected by taking sediment cores on exactly the same area. Afterwards, the samples were brought to the Institute of Oceanography - FCUL laboratory and were processed. $H$. portulacoides (above- and below-ground material) was carefully rinsed with demineralised water, and dried during $48 \mathrm{~h}$ (until it reached a constant weight) at $60^{\circ} \mathrm{C}$. Leaves, stems and belowground material were separated.

\subsection{Heavy metal extraction procedure}

A sequential extraction was performed (adapted from Farago and Pitt, 1977), in order to assess the metal content in cellular constituents of $H$. portulacoides. Vegetal material from different plant organs (leaves, stems and roots; $1 \mathrm{~g} \mathrm{DW} ; n=3$ ), previously homogenized, was processed individually in a soxhlet by successive extractions. The extracting agent used first was ethanol $80 \%$ (p.a., Merck, $150 \mathrm{ml}$ ) in reflux in a soxhlet for $12 \mathrm{~h}$; then, the residue was placed in $150 \mathrm{ml}$ of demineralised water and subjected 
to reflux for $12 \mathrm{~h}$. In the third extraction step, the residue was put in a solution of $100 \mathrm{ml}$ demineralised water $(\mathrm{pH}$ 7.5; temperature $37^{\circ} \mathrm{C}$ ) with $0.2 \mathrm{~g}$ pronase $\mathrm{E}$ (from Streptomyces griseus, Merck) plus $0.03 \mathrm{~g}$ chloramphenicol $(\geqslant 98 \%$, TLC) and subjected to continuous shaking for $24 \mathrm{~h}$. Later, the same residue was added to $100 \mathrm{ml}$ of a pectinase solution ( $1 \%$ P5146, Sigma; $\mathrm{pH} 4$, temperature $25^{\circ} \mathrm{C}$ ) and shaken for $24 \mathrm{~h}$. The following step consisted of a reflux of the residue in $150 \mathrm{ml} \mathrm{NaOH}$ solution $(0.5 \mathrm{M})$ (p.a. $\geqslant 98 \%$, Sigma) for $12 \mathrm{~h}$, and after that, another continuous reflux with $100 \mathrm{ml} \mathrm{HCl} \mathrm{5 \%} \mathrm{(prepared}$ from $\mathrm{HCl}$ fumant $37 \%$ p.a., Merck) was performed for $12 \mathrm{~h}$ at $25^{\circ} \mathrm{C}$. Lastly, an acid digestion of the plant residue was performed in Teflon bombs with $\mathrm{HNO}_{3} / \mathrm{HClO}_{4}$ (7:1, v:v) $\left(\mathrm{HNO}_{3} 65 \%\right.$ p.a., Merck; $\mathrm{HClO}_{4} 70 \%$ p.a. ACS-ISO, Panreac) and put into the oven at $110^{\circ} \mathrm{C}$ for $3 \mathrm{~h}$. After cooling, all extracts/fractions (ethanolic, aqueous, proteic, pectic, polissacaridic, lenhinic and cellulosic) were filtered through Whatman 42 filters (pore $\varnothing 2.5 \mu \mathrm{m}$ ) and diluted to $10 \mathrm{ml}$ with demineralised water.

Metals bound to pectic, polissacaridic, lenhinic and cellulosic fractions are those bound to the cell wall, since these are constituents of the cell wall. The different types of proteins can not be determined using this extraction method, which implies that its exact location in the cell can not be defined. The metals bound to some amino acids, chlorophyll, low weight compounds (all extracted by ethanol) and those extracted in the aqueous fraction were designated soluble metal (Farago and Pitt, 1977).

\subsection{Analytical procedures}

Metal concentrations in the $H$. portulacoides samples were determined by air-acetylene flame atomic absorption spectroscopy (VARIAN Spectr AA-50) and a manual microinjection method. The metal concentrations are reported in $\mu \mathrm{g} \mathrm{g}^{-1}$ dry weight (DW). Quality assurance was performed through stability of instrumental recalibration and using analytical blanks. Moreover, one certified reference material - CRM (Community Bureau of Reference - BCR 62, Olea europeae) was analysed to assess the validity and precision of the analytical procedures. The BCR was randomly allocated within the sample measurements. The analysed values for the reference material were in good agreement (not statistically different from the certified ones, $t$ student; $\alpha=0.05$ ), with the certified values and blanks proving to be negligible. The detection limits of the AAS analysis were in $\mathrm{mg} \mathrm{kg}^{-1}$ dry weight for: $\mathrm{Zn}$ (0.33), Pb (0.32), Co (0.13), Cd (0.03), Ni (0.15), Cu (0.03).

\subsection{Statistical analyses and calculations}

Two-way ANOVA (analysis of variance) was performed for each metal to test for differences in metal concentration between plant organs (three levels) and extracted fractions (seven levels). Dixon's test was performed to detect outliers. Data were $\log$-, $\log (x+1)-, 1 /(x+0.5)$ - or $x^{2}$-trans- formed when necessary, to achieve the homogeneity of variances (Cochran's $Q$ test). Normality of the data was also assured (Kolmogorov-Smirnov test). Post-hoc comparisons were performed using the Newman-Keuls test at $\alpha=0.05$ significance level. Analyses were performed with the STATISTICA 7.0 software package.

The translocation factor (TF) was calculated by the ratio of $[\text { metal }]_{\text {leaves }} /[\text { metal }]_{\text {roots }}$ and also by the ratio $[\mathrm{metal}]_{\text {stems }} /[\text { metal }]_{\text {roots }}$, expressing the metal's translocation within the plant, from the roots to the leaves and the stems (Deng et al., 2004). The TF from the sediment to the roots was also calculated.

\section{Results}

Total metal concentrations (sum of metals from all extracted fractions) from different organs (roots, stems and leaves) of $H$. portulacoides show a common pattern: $\mathrm{Zn}>\mathrm{Pb}>\mathrm{Cu}>\mathrm{Ni}>\mathrm{Co}>\mathrm{Cd}$, ranging between 290.89 $\mu \mathrm{g} \mathrm{g}^{-1} \mathrm{DW}$ of $\mathrm{Zn}$ in the roots to $5.10 \mu \mathrm{g} \mathrm{g}^{-1} \mathrm{DW}$ of $\mathrm{Cd}$ in the leaves (Table 1 and Fig. 1). Zn presents five to twenty seven times higher concentration than the other metals, both in the roots and in the above-ground material.

The roots present significantly higher metal concentrations than the stems and the leaves, for all studied metals (two-way ANOVA, $p<0.001$; Newman-Keuls test for post-hoc) (Fig. 1 and Table 2). Cd was the only metal where metal concentration in the leaves was significantly lower than in the stems, with all other metals presenting statistically the same concentrations in the leaves and the stems. The translocation of metals from the roots to the leaves can be expressed by the translocation factor (TF), and varied from $0.35 \pm 0.20(\mathrm{Cu})$ to $0.47 \pm 0.19(\mathrm{Zn})$ (Table 3). Instead, if we consider the TF for metals from the roots to the stems, it varied from $0.48 \pm 0.17$ for Co to $0.59 \pm 0.26$ for $\mathrm{Zn}, 0.59 \pm 0.27$ for $\mathrm{Pb}$ and $0.59 \pm 0.46$ for $\mathrm{Cd}$. The TF range from the sediment to the roots is from $0.11 \pm 0.05(\mathrm{~Pb})$ to $0.81 \pm 0.20(\mathrm{Ni})$, and there is an extreme value of $3.04 \pm 0.47(\mathrm{Cd})$. As was expected, the sediment presents higher metal concentrations than do the roots, with the exception of $\mathrm{Cd}$. According to the porewater metal concentrations (the metals really available to the plant), $\mathrm{Zn}$ and $\mathrm{Pb}$ presented the highest concentrations in the sediment. Considering all plant material (leaves, stems and roots), $\mathrm{Zn}$ and $\mathrm{Cd}$ are the metals with the highest TFs and $\mathrm{Cu}$ and $\mathrm{Co}$ with the lowest ones. $\mathrm{Cd}$ is the metal with the highest mobility also from the sediment to the roots, opposing Co with the lowest TF.

Regarding metal compartmentation in cell constituents, there was no statistically significant interaction between the plant organ and extracted fraction for each metal (two-way ANOVA, $p>0.05$; Table 2). Significantly higher $\mathrm{Zn}$ concentrations were present in the proteic fraction, and the lowest concentration was detected in cellulosis (Fig. 2). The highest $\mathrm{Pb}$ percentage occurs in the ethanolic and polissacaridic fractions. $\mathrm{Co}, \mathrm{Cd}$ and $\mathrm{Ni}$ were mostly accumulated in the polissacaridic fraction in all plant organs, 
Table 1

Metal concentrations ( $\mu \mathrm{g} \mathrm{g}^{-1} \mathrm{DW}$ ) (average $\pm \mathrm{SD} ; n=3$ ) on different fractions of Halimione portulacoides leaves, stems and roots, corresponding to extraand intra-cellular location

\begin{tabular}{|c|c|c|c|c|c|c|c|}
\hline \multirow[t]{2}{*}{ Plant organ } & \multirow[t]{2}{*}{ Fraction } & \multicolumn{6}{|c|}{ Metal $\left(\mu \mathrm{g} \mathrm{g}^{-1} \mathrm{DW}\right)($ average $\pm \mathrm{SD})$} \\
\hline & & $\mathrm{Zn}$ & $\mathrm{Pb}$ & $\mathrm{Co}$ & $\mathrm{Cd}$ & $\mathrm{Ni}$ & $\mathrm{Cu}$ \\
\hline \multirow[t]{8}{*}{ Roots } & Ethanolic & $28.34 \pm 11.84$ & $7.27 \pm 1.07$ & $1.55 \pm 0.46$ & $0.97 \pm 0.05$ & $2.84 \pm 0.63$ & $1.83 \pm 1.53$ \\
\hline & Aqueous & $33.37 \pm 26.01$ & $10.27 \pm 2.09$ & $2.01 \pm 0.35$ & $1.14 \pm 0.13$ & $3.11 \pm 0.90$ & $2.74 \pm 1.68$ \\
\hline & Proteic & $77.70 \pm 35.27$ & $5.30 \pm 1.81$ & $1.56 \pm 0.73$ & $1.15 \pm 0.54$ & $2.12 \pm 1.09$ & $7.70 \pm 3.61$ \\
\hline & Pectic & $53.40 \pm 32.27$ & $8.29 \pm 2.59$ & $1.76 \pm 0.49$ & $1.26 \pm 0.52$ & $2.27 \pm 0.65$ & $9.89 \pm 7.52$ \\
\hline & Polissacaridic & $19.44 \pm 7.31$ & $16.40 \pm 7.75$ & $9.58 \pm 4.90$ & $5.12 \pm 2.66$ & $11.95 \pm 5.38$ & $6.46 \pm 4.00$ \\
\hline & Lignin & $66.30 \pm 12.35$ & $7.57 \pm 1.40$ & $1.57 \pm 0.50$ & $1.30 \pm 0.26$ & $2.07 \pm 0.67$ & $6.43 \pm 3.57$ \\
\hline & Cellulosis & $12.33 \pm 9.01$ & $0.01 \pm 0.007$ & $1.47 \pm 1.25$ & $0.04 \pm 0.07$ & $2.30 \pm 0.00$ & $1.55 \pm 0.58$ \\
\hline & Total & 290.89 & 55.13 & 19.50 & 10.99 & 26.65 & 36.60 \\
\hline \multirow[t]{8}{*}{ Stems } & Ethanolic & $13.82 \pm 3.42$ & $5.23 \pm 3.10$ & $1.19 \pm 0.67$ & $0.89 \pm 0.45$ & $1.73 \pm 0.71$ & $1.92 \pm 0.31$ \\
\hline & Aqueous & $15.93 \pm 11.21$ & $4.99 \pm 2.40$ & $1.18 \pm 0.60$ & $0.85 \pm 0.44$ & $1.97 \pm 0.43$ & $1.79 \pm 0.98$ \\
\hline & Proteic & $78.90 \pm 44.55$ & $4.45 \pm 1.72$ & $1.01 \pm 0.17$ & $0.81 \pm 0.34$ & $1.48 \pm 0.47$ & $3.66 \pm 1.62$ \\
\hline & Pectic & $15.73 \pm 4.43$ & $4.13 \pm 1.49$ & $0.77 \pm 0.23$ & $0.63 \pm 0.18$ & $1.31 \pm 0.37$ & $1.56 \pm 1.64$ \\
\hline & Polissacaridic & $11.70 \pm 5.98$ & $8.61 \pm 3.24$ & $4.31 \pm 1.80$ & $2.69 \pm 0.90$ & $5.30 \pm 4.26$ & $3.38 \pm 0.95$ \\
\hline & Lignin & $26.43 \pm 9.46$ & $4.63 \pm 2.27$ & $0.93 \pm 0.61$ & $0.89 \pm 0.60$ & $1.50 \pm 0.76$ & $1.59 \pm 1.29$ \\
\hline & Cellulosis & $3.68 \pm 1.86$ & $0.00 \pm 0.00$ & $0.06 \pm 0.10$ & $0.29 \pm 0.36$ & $0.87 \pm 0.55$ & $0.70 \pm 0.36$ \\
\hline & Total & 166.19 & 32.04 & 9.47 & 7.04 & 14.14 & 14.60 \\
\hline \multirow[t]{8}{*}{ Leaves } & Ethanolic & $13.63 \pm 5.65$ & $5.27 \pm 1.02$ & $1.85 \pm 0.60$ & $1.15 \pm 0.33$ & $2.00 \pm 0.55$ & $3.08 \pm 1.85$ \\
\hline & Aqueous & $9.32 \pm 0.59$ & $3.98 \pm 1.23$ & $0.94 \pm 0.33$ & $0.65 \pm 0.23$ & $1.22 \pm 0.44$ & $0.97 \pm 0.43$ \\
\hline & Proteic & $46.15 \pm 24.16$ & $3.49 \pm 0.007$ & $0.71 \pm 0.17$ & $0.54 \pm 0.13$ & $1.00 \pm 0.24$ & $1.57 \pm 0.47$ \\
\hline & Pectic & $14.89 \pm 5.32$ & $2.80 \pm 0.34$ & $0.60 \pm 0.08$ & $0.44 \pm 0.07$ & $0.75 \pm 0.001$ & $2.29 \pm 2.06$ \\
\hline & Polissacaridic & $27.79 \pm 34.27$ & $2.56 \pm 2.75$ & $2.78 \pm 2.71$ & $1.69 \pm 1.53$ & $3.95 \pm 3.03$ & $2.61 \pm 2.00$ \\
\hline & Lignin & $16.62 \pm 13.44$ & $3.38 \pm 0.71$ & $0.73 \pm 0.21$ & $0.54 \pm 0.16$ & $0.99 \pm 0.27$ & $0.81 \pm 0.26$ \\
\hline & Cellulosis & $8.63 \pm 6.30$ & $0.51 \pm 0.46$ & $0.36 \pm 0.29$ & $0.10 \pm 0.02$ & $1.27 \pm 1.68$ & $0.73 \pm 0.24$ \\
\hline & Total & 137.03 & 21.99 & 7.96 & 5.10 & 11.18 & 12.05 \\
\hline
\end{tabular}

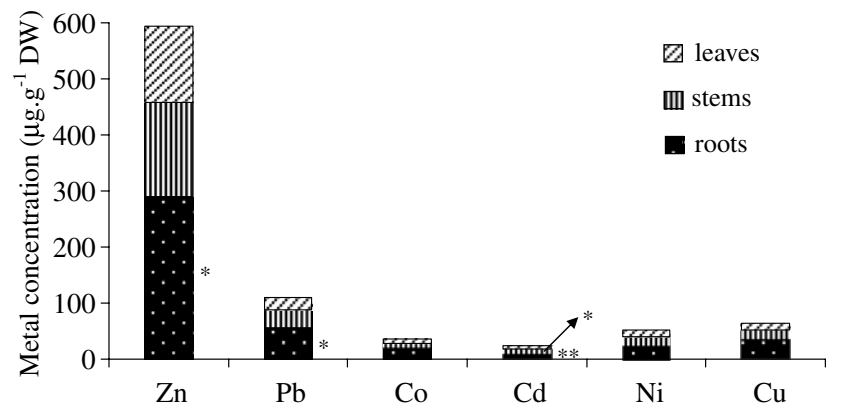

Fig. 1. Metal concentrations $\left(\mu \mathrm{g} \mathrm{g}^{-1} \mathrm{DW}\right)$ on $H$. portulacoides roots, stems and leaves, as a sum of all extracted fractions. $(*$ and $* *$ mean statistically different metal concentrations; two-way ANOVA, $p>0.05$ and Newman-Keuls' test for post-hoc).

and cellullosis was the fraction with the lowest concentration of these metals. $\mathrm{Cu}$ was mostly accumulated in ethanolic, proteic and pectic fractions.

Considering the extracted fractions, metal location in the plant can be divided into three sections: cell wall, proteic fraction and intracellular location (the soluble metals). Cell wall includes the pectic, polissacaridic, lenhinic and cellulosic fractions. The proteins exact location in the cell can not be determined by this extraction method. Intracellular metals include those extracted by ethanol and demineralised water (Figs. 3 and 4). Roots accumulate on average $21 \%$ of metals intracellularly (sum of the metal extracted with ethanol and demineralised water; average
Table 2

Two-way ANOVA: effects of plant organ and extracted fraction on $\mathrm{Zn}$, $\mathrm{Pb}, \mathrm{Co}, \mathrm{Cd}, \mathrm{Ni}$ and $\mathrm{Cu}$ extracted

\begin{tabular}{|c|c|c|c|c|c|}
\hline Metal & Source & $\mathrm{DF}$ & MS & $F$ & $p$ \\
\hline \multirow[t]{4}{*}{$\mathrm{Zn}$} & Plant organ & 2 & 0.804 & 10.323 & 0.0002 \\
\hline & Fraction & 6 & 0.827 & 10.624 & $<0.0001$ \\
\hline & Plant organ $\times$ fraction & 12 & 0.059 & 0.758 & 0.6885 \\
\hline & Residuals & 42 & 0.078 & & \\
\hline \multirow[t]{4}{*}{$\mathrm{Pb}$} & Plant organ & 2 & 31354.7 & 6.692 & 0.0032 \\
\hline & Fraction & 6 & 15378.4 & 3.282 & 0.0106 \\
\hline & Plant organ $\times$ fraction & 12 & 8232.2 & 1.757 & 0.0925 \\
\hline & Residuals & 38 & 4685.2 & & \\
\hline \multirow[t]{4}{*}{ Co } & Plant organ & 2 & 0.259 & 15.848 & $<0.0001$ \\
\hline & Fraction & 6 & 0.280 & 17.093 & $<0.0001$ \\
\hline & Plant organ $\times$ fraction & 12 & 0.023 & 1.408 & 0.2006 \\
\hline & Residuals & 42 & 0.016 & & \\
\hline \multirow[t]{4}{*}{$\mathrm{Cd}$} & Plant organ & 2 & 0.098 & 9.140 & 0.0005 \\
\hline & Fraction & 6 & 0.271 & 25.268 & $<0.0001$ \\
\hline & Plant organ $\times$ fraction & 12 & 0.016 & 1.490 & 0.1664 \\
\hline & Residuals & 42 & 0.011 & & \\
\hline \multirow[t]{4}{*}{$\mathrm{Ni}$} & Plant organ & 2 & 0.308 & 12.101 & 0.0001 \\
\hline & Fraction & 6 & 0.223 & 8.737 & $<0.0001$ \\
\hline & Plant organ $\times$ fraction & 12 & 0.014 & 0.545 & 0.8712 \\
\hline & Residuals & 40 & 0.025 & & \\
\hline \multirow[t]{4}{*}{$\mathrm{Cu}$} & Plant organ & 2 & 1.179 & 11.372 & 0.0001 \\
\hline & Fraction & 6 & 0.387 & 3.733 & 0.0046 \\
\hline & Plant organ $\times$ fraction & 12 & 0.151 & 1.453 & 0.1810 \\
\hline & Residuals & 42 & 0.104 & & \\
\hline
\end{tabular}

$\mathrm{Zn}$ and $\mathrm{Cu}$ data were log-transformed, $\mathrm{Co}$ and $\mathrm{Ni}$ data were $\log (x+1)$ transformed, $\mathrm{Cd}$ data were $1 /(x+0.5)$-transformed and $\mathrm{Pb}$ data were $x^{2}$ transformed, to achieve ANOVA assumptions in Ni two outliers were excluded, and in $\mathrm{Pb}$ four outliers were excluded (according to Dixon's test). 
Table 3

Translocation factors (TF) for metals within Halimione portulacoides plants from Tagus estuary $(n=3$; average \pm SD)

\begin{tabular}{|c|c|c|c|c|c|c|}
\hline \multirow[t]{2}{*}{ Translocation factor (TF) } & \multicolumn{6}{|l|}{ Metal } \\
\hline & $\mathrm{Zn}$ & $\mathrm{Pb}$ & Co & $\mathrm{Cd}$ & $\mathrm{Ni}$ & $\mathrm{Cu}$ \\
\hline$[\text { metal }]_{\text {leaves }} /[\text { metal }]_{\text {roots }}$ & $0.47 \pm 0.19$ & $0.41 \pm 0.11$ & $0.38 \pm 0.16$ & $0.43 \pm 0.09$ & $0.43 \pm 0.17$ & $0.35 \pm 0.20$ \\
\hline$[\text { metal }]_{\text {stems }} /[\text { metal }]_{\text {roots }}$ & $0.59 \pm 0.26$ & $0.59 \pm 0.27$ & $0.48 \pm 0.17$ & $0.59 \pm 0.46$ & $0.55 \pm 0.24$ & $0.50 \pm 0.30$ \\
\hline$[\text { metal }]_{\text {roots }} /[\text { metal }]_{\text {sediment }}$ & $0.51 \pm 0.07$ & $0.13 \pm 0.05$ & $0.11 \pm 0.05$ & $3.04 \pm 0.47$ & $0.81 \pm 0.20$ & $0.51 \pm 0.25$ \\
\hline
\end{tabular}
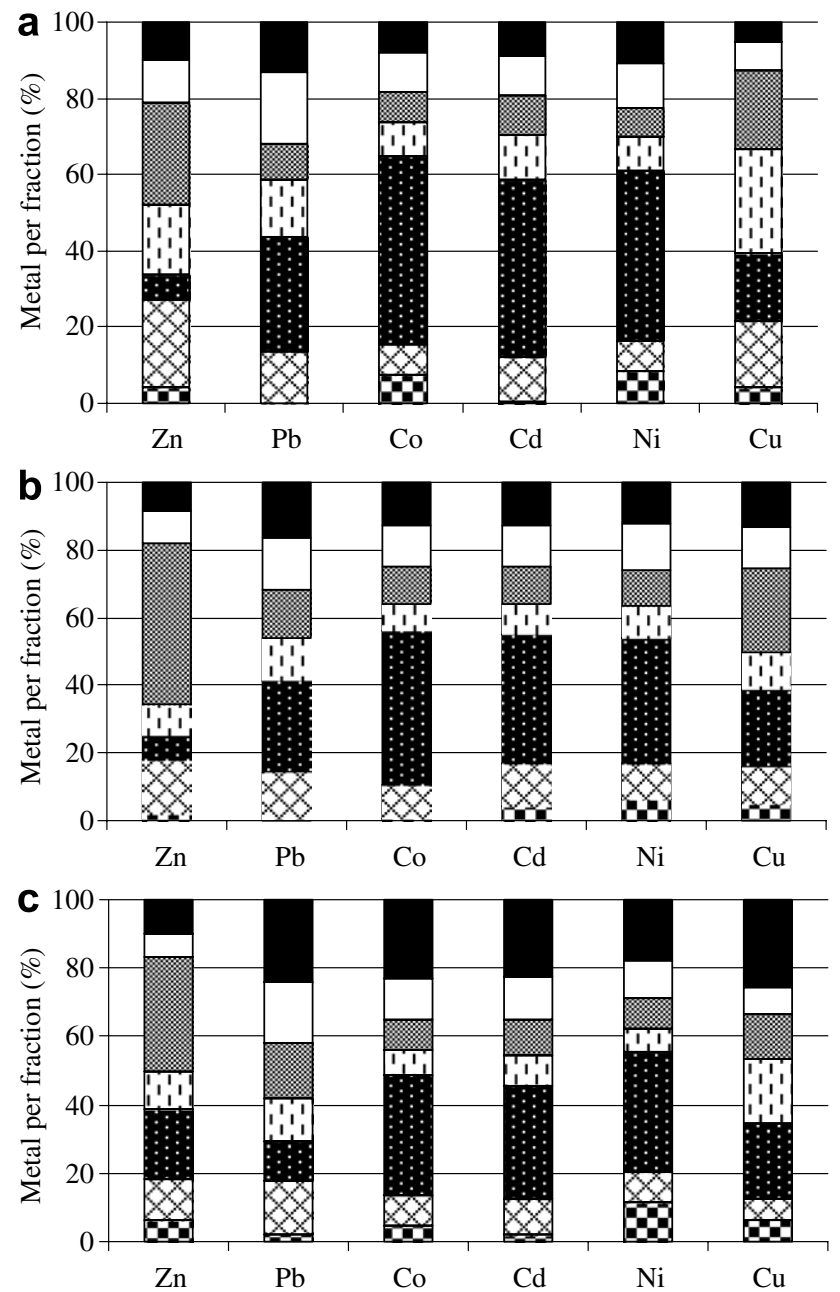

Fig. 2. Metal concentrations (\%) (average; $n=3$ ) on different fractions of H. portulacoides roots (a), stems (b), and leaves (c). The fractions, from top to down, are ethanolic ( $\square$ ), aqueous $(\square)$, proteic ( $\square$ ), pectic (四), polissacaridic (眳), lenhinic (圂) and cellulosic ( $\mathbf{Q})$.

for all metals), $14 \%$ is retained in the proteic fraction and $65 \%$ is in the cell wall (sum of metals quantified in the pectic, polissacaridic, lenhinic and cellullosic fractions). In the stems, on average $25 \%$ of metals are retained inside the cell, $20 \%$ the proteic fraction and the cell wall retain $55 \%$. The highest percentage of metals accumulated intracellularly occurs in the leaves (32\% average for all metals) and the proteic fraction presents $15 \%$. The cell walls of the leaves retain $53 \%$ of metals. $\mathrm{Co}, \mathrm{Cd}$ and $\mathrm{Ni}$ are the metals whose highest percentage is located in the cell wall of the leaves, stems and roots, whereas $\mathrm{Pb}$ presented the highest intracel- a

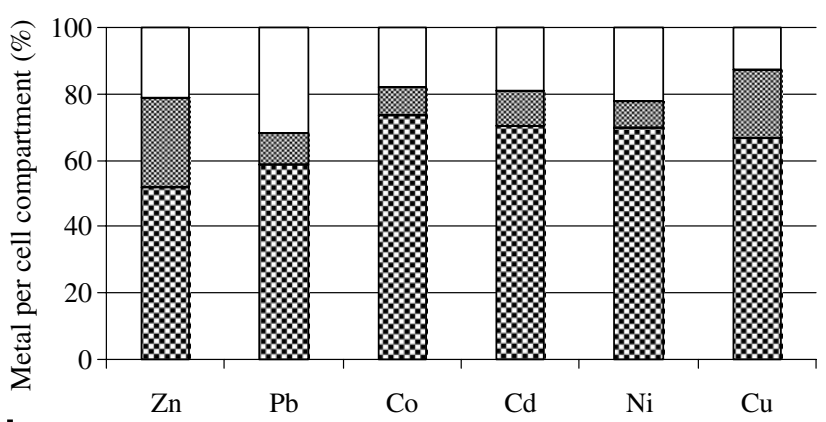

b

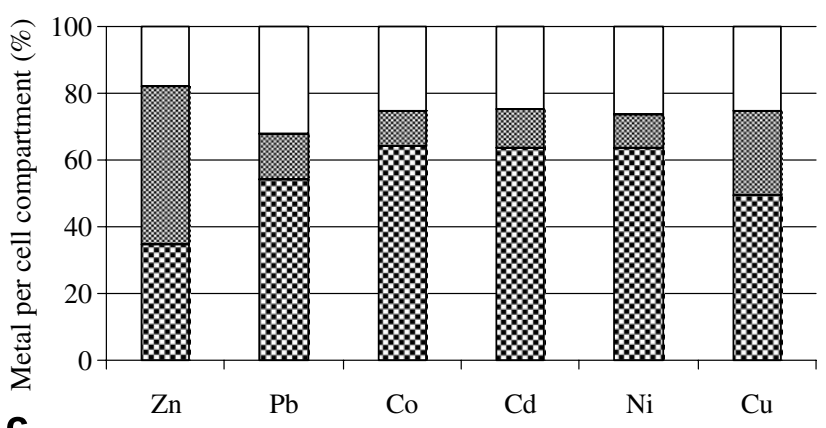

c

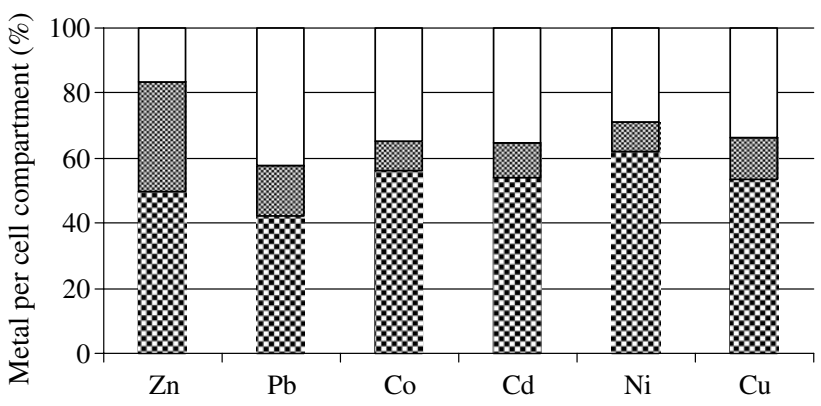

Fig. 3. Metal organic ligands (\%) (average; $n=3$ ) located intracellularly ( $\square$ ) (ethanolic + aqueous fraction), on the proteic fraction $(\square)$ and on the

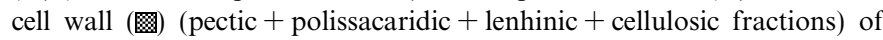
$H$. portulacoides roots (a), stems (b) and leaves (c), corresponding to extra- and intra-cellular location.

lular percentage. $\mathrm{Zn}$ was the metal presenting the highest percentage stored in the proteic fraction (Fig. 3).

\section{Discussion}

The results show that the roots (sum of all extracted fractions) of $H$. portulacoides accumulate much more metals than the above-ground parts (leaves and stems), which is in accordance with previous works on the Tagus estuary 


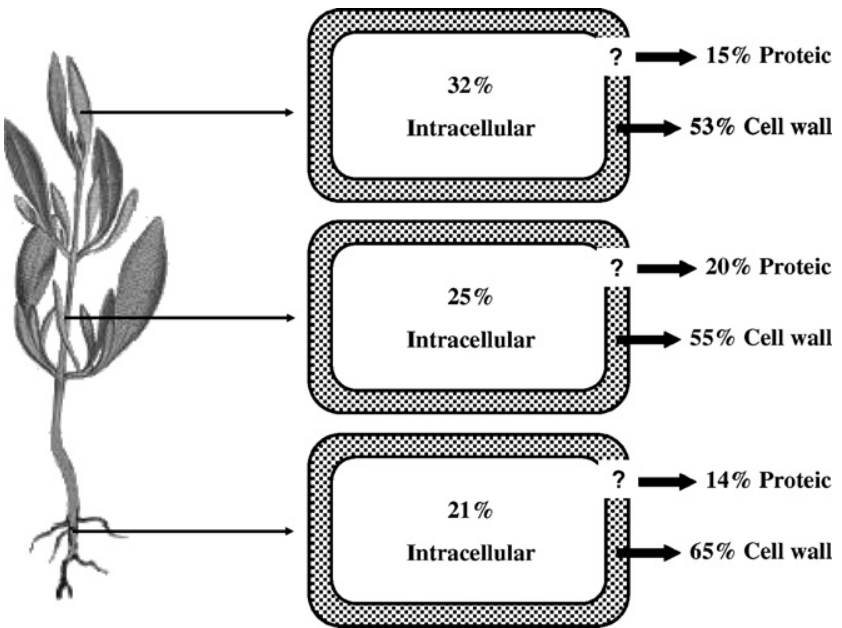

Fig. 4. Metal distribution and compartmentation (cell wall (圆), proteic fraction, and intracellular location ( $\square$ ) in Halimione portulacoides leaves, stems and roots.

(Caçador et al., 2000; Reboreda and Caçador, 2007). These results were also registered for $\mathrm{Cd}, \mathrm{Cu}, \mathrm{Zn}$ and $\mathrm{Pb}$ in several plant species by Stoltz and Greger (2002) and in other aquatic macrophytes from Australia (Cardwell et al., 2002). In Ireland, Spartina spp. present higher $\mathrm{Cu}$ and $\mathrm{Pb}$ concentrations in the below-ground material than in the above-ground (Fitzgerald et al., 2003); and the same results were obtained for zinc in a wetland grass (Glyceria fluitans) of five European populations (Matthews et al., 2004). In the Thames estuary H. portulacoides, Spartina spp. Salicornia spp. and Aster tripolium presented, in most cases, higher metal concentrations in the roots than in the above-ground (except for the most chemically mobile metals, Cd, Mn and Zn) (Williams et al., 1994). The Zn, Cu, $\mathrm{Cd}$ and $\mathrm{Pb}$ accumulated by the aquatic macrophyte Potamogeton natans were higher in the roots than in the stems or leaves (Fritioff and Greger, 2006). Nevertheless, metal concentration in the plant shoots can be higher than in the roots and, depending on the metals and on the plant species, there is a high variability. For instance, Paspalum distichum and Cynodon dactylon presented higher $\mathrm{Pb}, \mathrm{Zn}$ and $\mathrm{Cu}$ concentrations in the shoots rather than in the roots, when colonizing mine tailings contaminated sites as well as normal soils (Shu et al., 2002). Perronnet et al. (2003) showed that Thlaspi caerulescens shoots accumulate higher concentrations of $\mathrm{Zn}$ and $\mathrm{Cd}$ than its roots, which accumulate less than $20 \%$ of the hyperaccumulated metal in the plant.

The limited mobility of the metals once inside the salt marsh plant (Deng et al., 2004), which was observed in this study, may be the explanation for the fact that metals are essentially accumulated in the below-ground rather than in the above-ground part of salt marsh plants. This is also shown by translocation factors lower than 1 , which was seen in $H$. portulacoides for all the studied metals. The high mobility and bioavailability of $\mathrm{Zn}$ and Cd (Kiekens, 1995) may explain the highest translocation factors observed for these two metals, when considering the allocation of metals from the roots to the leaves and from the roots to the stems. The lowest TFs registered for $\mathrm{Cu}$, which is a relatively immobile metal in plants (Baker and Senft, 1995), render the higher accumulation of this metal in the roots, instead of being translocated to the leaves of $H$. portulacoides.

The sediment of the studied salt marsh, in relation to other contaminated sediments (e.g. Freitas et al., 2004), presented higher metal concentrations than $H$. portulacoides plant (Caçador et al., 2000; Reboreda and Caçador, 2007; this study). This is also rendered by the calculated TF from the sediment to the roots.

Uptake and accumulation of metals by salt marsh plants depend on many factors such as the plant species, the age and growth stage of the plants, seasonal variations, the existence of iron plaques on the roots, the level of metal contamination in a specific local, soil properties, tidal inundations, salinity; and then metal characteristics influence the absorption, accumulation and translocation of metals (Fitzgerald et al., 2003; Deng et al., 2004). Accordingly, plants have developed several strategies to survive in heavy metal contaminated soils. Tolerance mechanisms for $\mathrm{Zn}$ and $\mathrm{Ni}$ have been explained by its complexation with organic acids in the cell vacuoles (Marschner, 1995). In the well known hyperaccumulator Thlaspi caerulescens, the roots accumulate $\mathrm{Cd}$ both in the apoplast (binding to cell wall components) and inside the cells, as a Cd-detoxification mechanism; the leaves use vacuoles as the main compartment for $\mathrm{Cd}$ storage and detoxification (Wójcik et al., 2005). Phytochelatins had been defended as the main mechanism for metal detoxification in some plants (e.g. Cobbett, 2000), but the role of phytochelatins has been questioned by several authors (de Knecht et al., 1994, 1995; Ernst et al., 2000; Ebbs et al., 2002). On the other hand, according to Ramos et al. (2002) and Zornoza et al. (2002), lettuce leaves and lupin leaves, respectively, presented the most cellular $\mathrm{Cd}$ bound to cell wall fraction. In Brassica napus, Carrier et al. (2003) reported that the $\mathrm{Cd}$ is preferentially stored in the vacuoles and the cell walls, reducing the $\mathrm{Cd}$ toxicity in the leaves. Previous studies demonstrated that $T$. caerulescens (Salt et al., 1999), presents approximately half of the metal content as cell wall-bound, which was recently reinforced by Fritioff and Greger (2006), where T. caerulescens stored $24-59 \%$ of $\mathrm{Zn}, \mathrm{Cu}, \mathrm{Cd}$ and $\mathrm{Pb}$ in the cell wall-bound fraction.

In $H$. portulacoides all studied metals were found with a higher percentage bind to cell wall compounds, in roots, stems and leaves. However, the distribution of metals in different cell wall extracted fractions varied with the metal, which may be related to the properties of the metal themselves. It has been suggested that this higher accumulation of metals in cell walls works as a protection barrier against harmful effects by diminishing the metal concentration in the cytoplasm (Ramos et al., 2002; Zornoza et al., 2002).

This work shows that metal content in the intracellular compartment of $H$. portulacoides is much lower than the 
total metal content retained by the plant. Considering these data, it can be stated that compartmentation and detoxifying mechanisms are crucial for $H$. portulacoides to be able to tolerate high levels of heavy metals. Results show that the high levels of heavy metal in the salt marsh sediment, as well as those dissolved in the porewater (Reboreda and Caçador, 2007; Caçador, unpublished data) do not causes toxicity to the plants because the plant immobilizes them outside key metabolic sites. Thus, metal compartmentation in $H$. portulacoides constitutes a key mechanism of resistance in the plant. Metals are preferentially stored/ sequestered in compartments (vacuoles) and in the cell wall, away from metabolic active sites/compartments (such as cytoplasm, chloroplast, mithochondria) reducing the metal's toxicity in the plant (Frey et al., 2000; Psaras et al., 2000; Küpper et al., 2001; Psaras and Manetas, 2001; this study).

As a whole, metals are accumulated intracellularly in the plant and in different cell compartments, bound to different cell compounds (cell wall + proteic fraction + intracellular). The fact that the main percentage of metals is bound to the cell wall rather than located intracellullarly, may have crucial significance as a detoxifying mechanism in $H$. portulacoides leaves, stems and roots. This compartmentation may contribute to, and may be crucial to the survival of salt marsh plants in salt marshes that are highly contaminated by metal, since metals are immobilized outside metabolic active sites in the cell. This study gives an insight into the different compartmentation of $\mathrm{Zn}, \mathrm{Pb}, \mathrm{Cu}, \mathrm{Ni}$, $\mathrm{Co}$ and $\mathrm{Cd}$ inside $H$. portulacoides cells and plant organs (leaves, stems and roots) from the Tagus estuary. Thus, considering the $H$. portulacoides heavy metal storage capacity and its ability to immobilize metals in different compartments within the cell (functioning as a detoxification mechanism), this plant can be considered an important tool in phytoremediation processes.

\section{Acknowledgement}

This study was supported by the Portuguese Foundation for Science and Technology (FCT), in the scope of the research project POCTI/CTA/48386/2002.

\section{References}

Baker, D.E., Senft, J.P., 1995. Copper. In: Alloway, B.J. (Ed.), Heavy Metals in Soils, second ed. Blackie Academic and Professional, London, UK, pp. 179-205.

Caçador, I., Vale, C., Catarino, F., 1996. The influence of plants on concentration and fractionation of $\mathrm{Zn}, \mathrm{Pb}, \mathrm{Cu}$ in salt marsh sediments (Tagus estuary, Portugal). J. Aquat. Ecos. Health 5, 193-198.

Caçador, I., Vale, C., Catarino, F., 2000. Seasonal variation of $\mathrm{Zn}, \mathrm{Pb}, \mathrm{Cu}$ and $\mathrm{Cd}$ concentrations in the root-sediment system of Spartina maritima and Halimione portulacoides from Tagus estuary salt marshes. Mar. Environ. Res. 49, 279-290.

Cardwell, A.J., Hawker, D.W., Greenway, M., 2002. Metal accumulation in aquatic macrophytes from southeast Queensland, Austrália. Chemosphere 48, 653-663.
Carrier, P., Baryla, A., Havaux, M., 2003. Cadmium distribution and microlocalization in oilseed rape (Brassica napus) after long-term growth on cadmium-contaminated soil. Planta 216, 939-950.

Cobbett, C.S., 2000. Phytochelatins and their roles in heavy metal detoxification. Plant Physiol. 123, 825-832.

De Knecht, J.A., Van Dillen, M., Koevoets, P.M., Schat, H., Verkleij, J.A.C., Ernst, W.H.O., 1994. Phytochelatins in cadmium-sensitive and cadmium-tolerant Silene vulgaris. Plant Physiol. 104, 255-261.

De Knecht, J.A., van Baren, N., Ten Bookum, W.M., Wong Fong Sang, H.W., Koevoets, P.L.M., Schat, H., Verkleij, J.A.C., 1995. Synthesis and degradation of phytochelatins in cadmium-sensitive and cadmiumtolerant Silene vulgaris. Plant Sci. 106, 9-18.

Deng, H., Yea, Z.H., Wong, M.H., 2004. Accumulation of lead, zinc, copper and cadmium by 12 wetland plant species thriving in metalcontaminated sites in China. Environ. Pollut. 132, 29-40.

Ebbs, S., Lau, I., Ahner, B., Kochian, L., 2002. Phytochelatin synthesis is not responsible for $\mathrm{Cd}$ tolerance in the $\mathrm{Zn} / \mathrm{Cd}$ hyperaccumulator Thlaspi caerulescens ( $\mathrm{J}$ and C Presl). Planta 214, 635-640.

Ernst, W.H.O., Nelissen, H.J.M., Bookum, W.M.T., 2000. Combination toxicology of metal-enriched soils: physiological responses of a $\mathrm{Zn}$ and Cd-resistant ecotype of Silene vulgaris on polymetallic soils. Environ. Exp. Bot. 43, 55-71.

Farago, M.E., Pitt, M.J., 1977. Plants which accumulate metals. Part II. An investigation of the soluble zinc containing extracts from two Australian species. Inorg. Chim. Acta 24, 127-130.

Fitzgerald, E.J., Caffrey, J.M., Nesaratnam, S.T., McLoughlin, P., 2003. Copper and lead concentrations in salt marsh plants on the suir Estuary, Ireland. Environ. Pollut. 123, 67-74.

Freitas, H., Prasad, M.N.V., Pratas, J., 2004. Plant community tolerant to trace elements growing on the degraded soils of São Domingos mine in the south east of Portugal: environmental implications. Environ. Int. $30,65-72$.

Frey, B., Zierold, K., Brunner, I., 2000. Extracelular complexation of Cd in the hartig net and cytosolic $\mathrm{Zn}$ sequestration in the fungal mantle of Picea abies - Hebeloma crustuliniforme ectomycorrhizas. Plant Cell Environ. 23, 1257-1265.

Fritioff, A., Greger, M., 2006. Uptake and distribution of $\mathrm{Zn}, \mathrm{Cu}, \mathrm{Cd}$ and $\mathrm{Pb}$ in an aquatic plant Potamogeton natans. Chemosphere 63, 220 227.

Greger, M., 1999. Metal availability and bioconcentration in plants. In: Prasad, M.N.V., Hagemeyer, J. (Eds.), Heavy Metal Stress in Plants: From Molecule to Ecosystems. Springer-Verlag, Heidelberg, Berlin, Germany.

Greger, M., 2004. Metal availability, uptake, transport and accumulation in plants. In: Prasad, M.N.V. (Ed.), Heavy Metal Stress in Plants From Biomolecules to Ecosystems, second ed. Springer-Verlag, Heidelberg, Berlin, Germany, pp. 1-27.

Hall, J.L., 2002. Cellular mechanisms for heavy metal detoxification and tolerance. J. Exp. Bot. 53 (366), 1-11.

Kiekens, L., 1995. Zinc. In: Alloway, B.J. (Ed.), second ed., Heavy Metals in Soils Blackie Academic and Professional, London, UK, pp. 284 305.

Küpper, H., Lombi, E., Zhao, F., Wieshammer, G., McGrath, S.P., 2001. Cellular compartmentation of nickel in the hyperaccumulators Alyssum lesbiacum, Alyssum bertolonii and Thlaspi goesingense. J. Exp. Bot. 52, 2291-2300.

Liu, D., Kottke, I., 2003. Subcellular localization of Cd in the root cells of Allium sativum by electron energy loss spectroscopy. J. Biosci. 28, 471-478.

Lozano-Rodriguez, E., Hernandéz, L.E., Bonay, P., Carpena-Ruiz, R.O., 1997. Distribution of cadmium in shoot and root tissues of maize and pea plants: physiological disturbances. J. Exp. Bot. 48, 123-128.

Marschner, H., 1995. Mineral Nutrition of Higher Plants, second ed. Academic Press Limited, London, UK.

Matthews, D.J., Moran, B.M., McCabe, P.F., Otte, M.L., 2004. Zinc tolerance, uptake, accumulation and distribution in plants and protoplasts of five European populations of the wetland grass Glyceria fluitans. Aquat. Bot. 80, 39-52. 
Matthews, D.J., Moran, B.M., Otte, M.L., 2005. Screening the wetland plant species Alisma plantago-aquatica, Carex rostrata and Phalaris arundinacea for innate tolerance to zinc and comparison with Eriophorum angustifolium and Festuca rubra merlin. Environ. Pollut. 134, 343-351.

McCabe, O.M., Baldwin, J.L., Otte, M.L., 2001. Metal tolerance in wetland plants? Minerva Biotech. 13, 141-149.

Mellis, E.V., Cruz, M.C.P., Casagrande, J.C., 2004. Nickel adsoprtion by soils in relation to $\mathrm{pH}$, organic matter, and iron oxides. Sci. Agric. (Piracicaba, SP) 61, 190-195.

Otte, M.L., Matthews, D.J., Jacob, D.L., Moran, B.M., Baker, A.J.M., 2004. Biogeochemistry of metals in the rhizosphere of wetland plants an explanation for "innate" metal tolerance? In: Wong, M.H. (Ed.), Developments in ecosystems, vol. 1. Elsevier, pp. 87-94 (Chapter 6).

Perronnet, K., Schwartz, C., Morel, J.L., 2003. Distribution of cadmium and zinc in the hyperaccumulator Thlaspi caerulescens grown on multicontaminated soil. Plant Soil 249, 19-25.

Psaras, G.K., Constantinidis, Th., Cotsopoulos, B., Manetas, Y., 2000. Relative abundance of nickel in the leaf epidermis of eight hyperaccumulators: evidence that the metal is excluded from both guard cells and trichomes. Ann. Bot (London) 86, 73-78.

Psaras, G.K., Manetas, Y., 2001. Nickel localization in seeds of the metal hyperaccumulator Thlaspi pindicum Hausskn. Ann. Bot. (London) 88, 513-516.

Ramos, I., Esteban, E., Lucena, J.J., Gárate, A., 2002. Cadmium uptake and subcellular distribution in plants of Lactuca sp. Cd-Mn interaction. Plant. Sci. 162, 761-767.

Rauser, W.E., Ackerley, C.A., 1987. Localization of cadmium in granules within differentiating and mature root cells. Can. J. Bot. 65, 643-646.
Reboreda, R., Caçador, I., 2007. Halophyte vegetation influences in salt marsh retention capacity for heavy metals. Environ. Pollut. 146, 147154.

Salt, D.E., Prince, R.C., Baker, A.J.M., Raskin, I., Pickering, I.J., 1999. Zinc ligands in the metal hyperaccumulator Thlaspi caerulescens as determined using X-ray absorption spectroscopy. Environ. Sci. Technol. 33, 713-717.

Salt, D.E., Prince, R.C., Pickering, I.J., 2002. Chemical speciation of accumulated metals in plants: evidence from X-ray absorption spectroscopy. Microchem. J. 71, 255-259.

Sauvé, S., Hendershot, W., Allen, H.E., 2000. Solid-solution partitioning of metals in contaminated soils: dependence on $\mathrm{pH}$, total metal burden, and organic matter. Environ. Sci. Technol. 34, 1125-1131.

Shu, W.S., Ye, Z.H., Lan, C.Y., Zhang, Z.Q., Wong, M.H., 2002. Lead, zinc, and copper accumulation and tolerance in populations of Paspalum distichum and Cynodon dactylon. Environ. Pollut. 120, 445-453.

Stoltz, E., Greger, M., 2002. Accumulation properties of $\mathrm{As}, \mathrm{Cd}, \mathrm{Cu}, \mathrm{Pb}$ and $\mathrm{Zn}$ by four wetland plant species growing on submerged mine tailings. Environ. Exp. Bot. 47, 271-280.

Williams, T.P., Bubb, J.M., Lester, J.N., 1994. The occurrence and distribution of trace metals in halophytes. Chemosphere 28, 11891199.

Wójcik, M., Vangronsveld, J., D’Haen, J., Tukiendorf, A., 2005. Cadmium tolerance in Thlaspi caerulescens. II. Localization of cadmium in Thlaspi caerulescens. Environ. Exp. Bot. 53, 163-171.

Zornoza, P., Vázquez, S., Esteban, E., Fernández-Pascual, M., Carpena, R., 2002. Cadmium-stress in nodulated white lupin: strategies to avoid toxicity. Plant Physiol. Biochem. 40, 1003-1009. 